\title{
Effects of Nitrogen Fertilization on Subtropical Peach Fruit Quality: Organic Acids, Phytochemical Content, and Total Antioxidant Capacity
}

\author{
Tripti Vashisth ${ }^{1}$ \\ Horticultural Sciences Department, Citrus Research and Education Center, University of Florida, \\ Lake Alfred, FL 33850
}

\author{
Mercy A. Olmstead and James Olmstead \\ Horticultural Sciences Department, University of Florida, Gainesville, FL 32611 \\ Thomas A. Colquhoun \\ Environmental Horticulture Department and Plant Innovation Center, University of Florida, \\ Gainesville, FL 32611
}

\begin{abstract}
AdDitional Index words. harvest date, health benefits, stone fruit
Abstract. Producing temperate-zone fruit crops in subtropical environments requires alterations in fertilizer application and rates. Nitrogen $(N)$ is a critical mineral nutrient required in high amounts by the tree; however, it is often over- or under-applied for optimal fruit quality and can affect the phytochemical composition of fruits. The effects of different $\mathbf{N}$ fertilizer rates and harvest date on total phenolic content, total flavonoid content, total anthocyanins, total antioxidant capacity, total soluble solids, titratable acidity, and organic acids (citric and malic acid) of two subtropical peach (Prunus persica) cultivars, TropicBeauty and UFSharp, were investigated. $\mathrm{N}$ rate did not affect total soluble solids in 'TropicBeauty', although total soluble solids decreased as $\mathbf{N}$ rate increased in 'UFSharp'. Titratable acidity and organic acid content was significantly higher in 'UFSharp' as compared with 'TropicBeauty', although there was no effect of $\mathrm{N}$ rate on titratable acidity. An overall increase in phenolic content, flavonoid content, anthocyanins, and antioxidant capacity were observed with decreasing $\mathbf{N}$ rates in both subtropical peach cultivars. A stronger genotype $\times \mathbf{N}$ treatment interaction was observed for 'TropicBeauty' for phenolic content, flavonoid content, and antioxidant capacity than for 'UFSharp'. In 'TropicBeauty', among the treatments with no $\mathrm{N}$ and highest $\mathrm{N}$, an almost $100 \%$ increase in phenolic content, $200 \%$ increase in flavonoid content, $50 \%$ increase in anthocyanin content, and $80 \%$ increase in antioxidant activity was observed. A positive correlation among phenolic content, flavonoid content, and antioxidant capacity was observed in both 'TropicBeauty' and 'UFSharp'. Late harvest date decreased phenolic content in 'TropicBeauty', ranging from $6 \%$ to $32 \%$ among different $N$ treatments. Late harvest increased anthocyanin content as compared with fruit that were harvested on early dates. The results suggest that subtropical peach phytochemical composition can be affected by different cultivars and tree age, and can be manipulated with cultural practices like $\mathbf{N}$ fertilization and harvest time to produce fruit with altered or desired nutritional composition for consumers.
\end{abstract}

As consumers learn about the health benefits of fruits (Prior and Cao, 2000), they are demanding fruit with higher antioxidant and phytochemical capacities, as clearly demonstrated by the popularity of fruits (Gilbert et al., 2014; Olmstead et al., 2015). Increased consumption of fruits has been associated with potential protection against age-related diseases (Ames et al., 1993). A clear inverse relationship between the consumption of fruits and incidences of cardiovascular and cerebrovascular degenerative proliferative diseases, oxidative stress, and mortality has been largely supported by a number of epidemiological studies (Ames et al., 1993; Ko et al., 2005; Sun et al., 2002). In a consumer survey conducted by researchers at the University of Florida, 39\% of the consumers identified health benefits as the most influential factors for southern highbush blueberry (Vaccinium darrowii) fruit consumption; whereas, $61 \%$ of the

Received for publication 21 Dec. 2016. Accepted for publication 28 July 2017. Funding for this project was made possible by the University of Florida, Institute of Food and Agricultural Sciences Early Career Scientist Award Program. We thank the UF/IFAS Research office for their support.

${ }^{1}$ Corresponding author. E-mail: tvashisth@ufl.edu. consumers suggested the flavor was more critical for southern highbush blueberry consumption (Gilbert et al., 2014), indicating a high number of consumers are paying attention to health benefits of fruits over other attributes and often base their decision of consumption on the health benefits offered.

Fruits are excellent functional foods as they are high in antioxidant capacity and phytochemicals (Scalzo et al., 2005; Tomas-Barberan and Robins, 1997). Phytochemicals are naturally occurring substances that play an important role in the visual appearance and flavor. Phytochemicals comprise numerous compounds such as polyphenolics, carotenoids, alkaloids, etc., and are well known for imparting antioxidant activity. Antioxidants act as scavenging agents for harmful free radicals, which have been implicated in the aging process and many degenerative diseases (Harman, 1981; Rice-Evans et al., 1996). Polyphenolic compounds are secondary plant metabolites, and their redox properties allow them to act as reducing agents, hydrogen donors, and singlet oxygen quenchers (Fukumoto and Mazza, 2000; Prior et al., 2005; Rice-Evans et al., 1996). One of the largest classes of polyphenolic compounds in fruits and vegetables is flavonoids. Flavonoids are very well characterized 
for their free radical scavenging activity. Flavonoid radicals have lower reduction potential than in alkyl peroxyl radicals, and the superoxide radical, meaning flavonoids have the potential to inactivate these oxyl species and prevent the deleterious consequence of their reactions (Jovanovic et al., 1992; Rice-Evans et al., 1996; Sogawa et al., 1993). Anthocyanins, a flavonoid, are natural, water soluble pigments found in flower, fruit, and leaves. Anthocyanins contain potent antioxidant properties modulated by their different hydroxylation and glycosylation (Rice-Evans et al., 1996). In addition to their health benefits, flavonoids, and other phenolic compounds are important for normal plant growth development, fruit and flower color development, and defense against ultraviolet light, pathogens, insect herbivory, and other biotic and abiotic stresses (Benoit and Berry, 1997; Berhow and Vaughn, 1999; Brignolas et al., 1998; Murphy et al., 2000; Ryan et al., 2002).

Subtropical peaches are greatly appreciated for their great taste, flavor, and aroma. Ideal subtropical peach fruit quality and high nutritive value drives consumer satisfaction measured by initial and repeat consumer purchases (Colaric et al., 2005; Delgado et al., 2013; Hudina and Stampar, 2000; Olmstead et al., 2015). In addition to excellent fruit taste, subtropical peaches are also a good source of vitamin $\mathrm{C}$ and have a fair amount of antioxidant activity (Cantín et al., 2009). Olmstead et al. (2015) conducted an IdeaMap (Moskowitz Jacobs, White Plains, NY) consumer survey to identify "ideal" subtropical peach attributes that contribute to repeated consumer purchase. According to the survey, vitamin $\mathrm{C}$ scored high after flavor and texture, suggesting consumers prefer high nutrient value in subtropical peaches. In subtropical peaches, the primary source of antioxidant capacity is polyphenolic compounds (Gil et al., 2002). The major anthocyanins in subtropical peach are cyanidin-3-glucoside and cyanidin-3-rutinoside (Tomas-Barberan et al., 2001).

Production of subtropical peach cultivars requires alterations in cultural practices as the active growth period is considerably longer than in temperate production areas. It has been suggested that these practices may influence overall fruit quality and polyphenolic compound concentrations in fruits. Overall fruit quality, distribution and composition of phenolic phytochemicals are affected by maturity, cultivars, horticultural practices, fertilization, geographic origin, growing season, postharvest storage conditions, and processing procedures (Burda et al., 1990; De Freitas and Glories, 1999; Donovan et al., 1998; Kalt et al., 1999; Kim et al., 2001; Lee and Jaworski, 1987; Spanos and Wrolstad, 1990). Phytochemical composition is strongly influenced by genotypes; different cultivars can produce different concentrations of total phenolic compounds as well as specific phenolic compounds (Atkinson et al., 2006; Buendia et al., 2010). Cantín et al. (2009) reported that the phytochemical profiles of subtropical peach genotypes varied depending on yellow/white flesh color, and antioxidant capacity was positively correlated to total phenolic content. $\mathrm{N}$ fertilization has been reported to affect phenolic content in several different fruits and vegetables such as chinese cabbage [Brassica chinensis (Zhu et al., 2009)], broccoli [Brassica oleracea var. italica (Jones et al., 2007)], apple [Malus domestica (Reay et al., 1998)], basil [Ocimum basilicum (Nguyen and Niemeyer, 2008)], lettuce [Lactuca sativa (CoriaCayupan et al., 2009)], tomato [Solanum lycopersicum (Bénard et al., 2009)], olive [Olea europaea (Fernandez-Escobar et al., 2006)], and strawberry [Fragaria ananassa (Anttonen et al., 2006)]. In all these examples, an increase in phenolic content has been observed with application of reduced $\mathrm{N}$ rates. High $\mathrm{N}$ rates in olives and grapes (Vitis vinifera) have reduced polyphenol concentration, including anthocyanins, and resulted in decline of overall oil and wine quality, respectively (Fernandez-Escobar et al., 2006; Hilbert et al., 2003; Keller and Hrazdina, 1998; Malusà et al., 2004; Schreiner et al., 2013; Wade et al., 2004). $\mathrm{N}$ rate can also affect fruit quality parameters such as total soluble solids [TSS (sweetness indicator)] and titratable acidity [TA (acidity indicator)]. Sweetness, acidity, and astringency are key traits that are positively correlated with overall liking for subtropical peach fruit (Olmstead et al., 2015; Predieri et al., 2006). The effect of $\mathrm{N}$ on TSS and TA has been reported in a number of fruit crops such as grape (Bavaresco et al., 2001), apple (Nava et al., 2008), and tomato (Simonne et al., 2007). Another factor that can influence the fruit quality and phytochemical content of fresh produce is the fruit developmental stage and harvest time. Fruit ripening stage can strongly influence the content of TSS, TA, and phenolic compounds as well as total antioxidant activity of fruit extracts (Guerra and Casquero, 2008; Tulipani et al., 2008).

The production of temperate zone fruit crops in subtropical environments has increased significantly in the last 30 years. Interest continues to grow because of two factors: 1) early flowering and fruit set result in growers being able to harvest fruit earlier in the domestic market window (Morgan and Olmstead, 2013), giving higher economic returns, and 2) breeding advances have resulted in availability of lowchill accumulating plants that provide alternatives for growers seeking to diversify (Byrne and Bacon, 1999). Low-chill cultivars of apple (Hough and Bonnetti, 1988), southern highbush blueberry, plum (Prunus domestica), and subtropical peach (Lyrene, 2005; Sherman and Lyrene, 1985) have been developed by several breeding programs and are in commercial production (Byrne and Bacon, 1999). Currently, we lack in understanding of the effect of preharvest production practices on the fruit quality of subtropical peaches. As the production of subtropical peaches continues to increase in southeast United States, there is a desperate need to ensure that the production practices such as fertilization and harvest time are optimized to yield high quality, nutritious fruit, in addition to optimum production. Therefore, in the present study, we focused on the impact of different rates of $\mathrm{N}$ fertilization on fruit quality including organic acid, TSS, TA, total phenolic content (phenolic content), total flavonoid content (flavonoid content), total anthocyanin content (anthocyanin content), and total antioxidant capacity (antioxidant capacity) of subtropical peaches. We hypothesize that increasing $\mathrm{N}$ rate will lead to lower phytochemical content, whereas later harvest dates will favor higher phytochemical content. The two subtropical peach cultivars used in this study are TropicBeauty (melting texture) and UFSharp (nonmelting texture). 'Tropic Beauty' is one of the most popular low-chill subtropical peach cultivars; the medium-sized, semifreestone fruit have yellow, melting flesh and develop 70\% blush over a yellow ground color, and have low firmness. 'UFSharp' fruit develop 60\% red blush over a deep yellow to orange ground color with excellent fruit size, shape, and firmness.

\section{Materials and Methods}

Chemicals. All chemicals were of analytical grade. 3,4,5trihydroxybenzoic acid (gallic acid), acetic acid $\left(\mathrm{CH}_{3} \mathrm{COOH}\right)$, 
aluminum chloride $\left(\mathrm{AlCl}_{3}\right)$, catechin, Folin-Ciocalteu's phenol reagent, ferrous sulphate heptahydrate $\left\{\mathrm{TPTZ}\left[\left(\mathrm{FeSO}_{4} \cdot 7 \mathrm{H}_{2} \mathrm{O}\right)\right.\right.$, 2,4,6-tris (2-pyridyl)-s-triazine]\}, ferric chloride hexahydrate $\left(\mathrm{FeCl}_{3} \cdot 6 \mathrm{H}_{2} \mathrm{O}\right)$, hydrochloric acid $(\mathrm{HCl})$, potassium chloride $(\mathrm{KCl})$, sodium carbonate $\left(\mathrm{Na}_{2} \mathrm{CO}_{3}\right)$, sodium hydroxide $(\mathrm{NaOH})$, sodium acetate $\left(\mathrm{CH}_{3} \mathrm{COONa}\right)$, and sodium nitrate $\left(\mathrm{NaNO}_{2}\right)$ were purchased from Sigma-Aldrich (St. Louis, MO).

Plant material. Experiment 1 investigated the effects of $\mathrm{N}$ fertilization rate on fruit quality of subtropical peach cultivars TropicBeauty and UFSharp. Experiment 2 investigated the effects of harvest date (early, mid, and late harvest) on the fruit quality in 'TropicBeauty'. Experiment 1 used 4-year-old subtropical peach trees of 'TropicBeauty' and 'UFSharp' grafted on 'Flordaguard' rootstock planted at $7.6 \mathrm{~m}$ between rows and $4.8 \mathrm{~m}$ between trees grown at the University of Florida Plant Science Research and Education Unit, Citra, FL (UF PSREU). The experimental design was a split plot design $(N=4)$, where a set of five trees were regarded as one replicate. Five rates of $\mathrm{N}$ treatment $\left(0,45,90,179\right.$, and $269 \mathrm{~kg} \cdot \mathrm{ha}^{-1}$ per year $)$ were in the form of ammonium nitrate $\left[\mathrm{NH}_{4} \mathrm{NO}_{3}\right.$ (Liberty Acres Fertilizer, Darlington, SC)] were applied annually from the time of planting (2010). The fertilizer was applied through the irrigation system and was divided into 12 applications per year. The trees were pruned, irrigated, and fruit-thinned according to standard industry practices to minimize the environmental component (Olmstead et al., 2013). Fruit from both cultivars, TropicBeauty and UFSharp, were harvested on 11 June 2014. All of the fruit meeting commercially accepted standards for ground color and fruit size (Crisosto and Valero, 2008) were harvested by trained harvesters. A subsample $(\approx 10$ pieces of fruit) of harvested fruit was immediately pitted, chopped with skin, frozen in liquid nitrogen, and stored at $-80{ }^{\circ} \mathrm{C}$ until samples were processed for further analysis.

Experiment 2 used 7-year-old 'TropicBeauty' trees grafted to 'Flordaguard' rootstock planted $7.6 \mathrm{~m}$ between rows and $4.8 \mathrm{~m}$ between trees and grown at the UF PSREU. Treatments were replicated in a completely randomized design $(N=3)$, where two trees were regarded as one replicate (number of replicates were reduced in this experiment due to limitation in available trees). Four rates of $\mathrm{NH}_{4} \mathrm{NO}_{3}\left(45,90,179\right.$, and $269 \mathrm{~kg} \cdot \mathrm{ha} \mathrm{a}^{-1}$ per year) were applied annually, plus a no $\mathrm{N}$ control $\left(0 \mathrm{~kg} \cdot \mathrm{ha}^{-1}\right.$ per year). These treatments were initiated in 2011 when the trees were 4 years old; before initiation of $\mathrm{N}$ treatments, all of the trees were on the same fertilization program $\left(90 \mathrm{~kg} \cdot \mathrm{ha}^{-1}\right.$ per year $\left.\mathrm{N}\right)$. Trees were pruned, irrigated, and fruit thinned according to standard industry practices to minimize the environmental component (Olmstead et al., 2013). All of the fruit meeting commercially accepted standards for ground color and fruit size (Crisosto and Valero, 2008) were harvested by trained harvesters. Harvests occurred on 22 May 2014, 2 June 2014, and 12 June 2014, representing early, mid, and late harvests, respectively (commercial harvest date for 'Tropic Beauty' was in the same date range). A subsample of harvested fruit was immediately pitted, chopped with skin, and frozen in liquid nitrogen and stored at $-80{ }^{\circ} \mathrm{C}$ until samples were processed for further analysis.

Fruit QUALity anAlysis. TSS and TA were measured for a subset of chopped fruit. One hundred $( \pm 0.5)$ grams of chopped fruit were homogenized and centrifuged at $5000 \mathrm{~g}_{\mathrm{n}}$ for $10 \mathrm{~min}$ (Sorvall Legend XTR Refrigerated; Thermo Fisher Scientific, Waltham, MA). The supernatant of homogenate was used for measuring TSS with a refractometer (Pocket PAL-1; Atago USA, Bellevue, WA) and TA with a titrator (808 Titrando;
Metrohm, Riverview, FL). Titratable acidity was determined by titrating $6 \mathrm{~mL}$ of juice with $0.1 \mathrm{~N} \mathrm{NaOH}$ to a $\mathrm{pH}$ endpoint of 8.2. The results were expressed as percent malic acid. The ripening index (RI) was calculated as the TSS/TA ratio.

Citric and malic acid concentrations were determined by using the enzymatic ultraviolet method. Quantification was done using kits for citric acid and L-malic (catalog no. 10139076035 and no. 10139068035 ; R-Biopharm, Darmstadt, Germany). Briefly, the frozen fruit material was homogenized to a fine powder without letting it thaw and then $1 \mathrm{~g}$ fresh weight $(\mathrm{FW})$ of fine powder was mixed with $1 \mathrm{~mL}$ deionized water at room temperature. Clear supernatant was removed from each sample after centrifugation and citric and L-malic acid quantification was done as per manufacturer's instructions. Absorbance was measured at $340 \mathrm{~nm}$ on a spectrophotometer (Epoch Microplate; Biotek, Winooksi, VT). Results were reported as milligram per milliliter of subtropical peach juice.

Phytochemical analysis. Hydrochloric acid extraction was used for quantification of phenolic content, flavonoid content, anthocyanin content, and antioxidant activity as described by Cantín et al. (2009). Briefly, the frozen fruit material was homogenized to fine powder without letting it thaw and then $5 \mathrm{~g}$ of fine powder was mixed with $15 \mathrm{~mL}$ of extraction solution, consisting of $0.5 \mathrm{~N} \mathrm{HCl}$ in methanol/Milli-Q water $(80 \% \mathrm{v} / \mathrm{v}$; Millipore Sigma, Billerica, MA). The mixture was incubated overnight at $4{ }^{\circ} \mathrm{C}$ and then centrifuged for $20 \mathrm{~min}\left(20,000 g_{\mathrm{n}}\right)$ at $4{ }^{\circ} \mathrm{C}$. The supernatant was recovered and used for further phytochemical analysis.

Phenolic content of extracts was determined by the FolinCiocalteu assay as described by Vashisth et al. (2011). Briefly, $0.5 \mathrm{~mL}$ of extract was pipetted into a test tube containing $8 \mathrm{~mL}$ of deionized water. Then, $0.5 \mathrm{~mL}$ of Folin-Ciocalteu's phenol reagent (Millipore Sigma) was added and followed by $1 \mathrm{~mL}$ of a saturated $\mathrm{Na}_{2} \mathrm{CO}_{3}$ solution. The contents in each test tube were vortexed for $10 \mathrm{~s}$ and left to stand at room temperature for $1 \mathrm{~h}$ to allow for maximum color development. Three hundred microliter aliquots were transferred from each test tube into a 96-well microtitre plate and absorbance readings were taken at $750 \mathrm{~nm}$ using a spectrophotometer (Synergy HTX Multimode Reader; Biotek). The standard curve was constructed with varying concentrations from a stock solution by dissolving $80 \mathrm{mg}(470.2 \mu \mathrm{mol})$ of gallic acid in $25 \mathrm{~mL}$ of methanol and then diluting it with deionized water to $1 \mathrm{~L}$. The total phenolic contents of samples were expressed as gallic acid equivalents [GAE (milligram per $100 \mathrm{~g} \mathrm{FW)].}$

Flavonoid content was determined using a colorimetric assay (Zhishen et al., 1999). One milliliter of extract was diluted with water $(1: 2)$, and $0.3 \mathrm{~mL}$ of $5 \% \mathrm{NaNO}_{2}$ was added. After $5 \mathrm{~min}, 0.3 \mathrm{~mL}$ of $10 \% \mathrm{AlCl}_{3}$ was added. After $1 \mathrm{~min}, 2 \mathrm{~mL}$ of $1 \mathrm{~N} \mathrm{NaOH}$ was added and vortexed. Absorbance was measured at $510 \mathrm{~nm}$. The results were expressed as catechin equivalents [CAE (milligram per $100 \mathrm{~g} \mathrm{FW}$ )] on the basis of a standard curve using catechin as a standard.

Anthocyanin content was determined by the $\mathrm{pH}$-differential method (Lee et al., 2005). Briefly, $1 \mathrm{~mL}$ extracted solution was dissolved into a $10-\mathrm{mL}$ volumetric flask and used to prepare two dilutions of the sample: one adjusted volume with $\mathrm{KCl}$ buffer, $\mathrm{pH}$ 1.0, and the other with $\mathrm{CH}_{3} \mathrm{COONa}$ buffer, $\mathrm{pH}$ 4.5. After solutions were equilibrated, the absorbance of each dilution was measured at 510 and $700 \mathrm{~nm}$ against a blank cell filled with distilled water. The absorbance of diluted samples was calculated as follows: 


$$
A=\left(A_{510}-A_{700}\right) \mathrm{pH} 1.0-\left(A_{510}-A_{700}\right) \mathrm{pH} 4.5
$$

where $A$ is the absorbance of sample at 510 and $700 \mathrm{~nm}$.

The monomeric anthocyanin pigments were calculated by using the formula below:

$$
\begin{aligned}
& \text { Monomeric anthocyanin pigment } \\
& =(A \times \mathrm{MW} \times \mathrm{DF} \times 1000) /(\varepsilon \times 1)
\end{aligned}
$$

where MW is the molecular weight, DF is the dilution factor, and $\varepsilon$ is the molar absorptivity, calculate pigment content as cyanidin-3-glucoside, where MW $=449.2$ and $\varepsilon=26,900$ and results expressed as cyanidin-3-glucoside equivalents [C3GE (milligram per kilogram $\mathrm{FW}$ )].

Antioxidant Capacity. Two assays that are commonly used to measure antioxidant capacity are the ORAC assay (oxygen radical absorption capacity) for the hydrogen atom transfer mechanisms and the FRAP assay (ferric reducing antioxidant power) for the single electron transfer mechanisms. The FRAP assay measures the reducing power of samples (Benzie and Szeto, 1999) and, therefore, indicates a better antioxidant capacity of a given product. Total antioxidant activity of prepared extracts was determined by the FRAP assay as described by Pulido et al. (2000) with modifications. The FRAP reagent was prepared fresh by combining $5 \mathrm{~mL}$ of a $10-\mathrm{mmol} \cdot \mathrm{L}^{-1} \mathrm{TPTZ}$ solution in $40 \mathrm{mmol} \cdot \mathrm{L}^{-1} \mathrm{HCl}$ with $5 \mathrm{~mL}$ of $20 \mathrm{mmol} \cdot \mathrm{L}^{-1} \mathrm{FeCl}_{3} \cdot 6 \mathrm{H}_{2} \mathrm{O}$ and $50 \mathrm{~mL}$ of a $0.3 \mathrm{~mol} \cdot \mathrm{L}^{-1}$ $\mathrm{CH}_{3} \mathrm{COONa}$ buffer at $\mathrm{pH}$ 3.6. The FRAP reagent was warmed to $37^{\circ} \mathrm{C}$ in a water bath (Isotemp model 2239; Thermo Fisher Scientific) and held at this temperature until used. Aqueous solutions of known $\mathrm{Fe}$ (II) $\left(\mathrm{FeSO}_{4} \cdot 7 \mathrm{H}_{2} \mathrm{O}\right)$ concentrations in the range of 100 to $2400 \mu \mathrm{mol} \cdot \mathrm{L}^{-1}$ were used to construct the standard curve. In a microtitre plate, $1500 \mu \mathrm{L}$ of FRAP reagent were mixed with $150 \mu \mathrm{L}$ of deionized water and $50 \mu \mathrm{L}$ of the test sample or blank (i.e., 1:1 aqueous methanol). Before reading the absorbance, the plate was incubated at $37{ }^{\circ} \mathrm{C}$ for $30 \mathrm{~min}$ and agitated for $5 \mathrm{~s}$; the absorbance readings of the samples $\left(\right.$ at $37{ }^{\circ} \mathrm{C}$ ) were recorded at $595 \mathrm{~nm}$. Antioxidant activity of the prepared extracts was expressed as Ferrous equivalents $\left[\mathrm{Fe}^{2+} \mathrm{E}\right.$ (millimoles per gram $\left.\left.\mathrm{FW}\right)\right]$.

Statistical analysis. All statistical analyses were performed using two-way analysis of variance (ANOVA) at $\alpha=0.05$ using SigmaPlot (version 11; Systat Software, San Jose, CA). Mean separation among treatments with significant differences was performed using Tukey's honest significance test (HSD) at $\alpha=0.05$.

\section{Results}

EXPERIMENT 1. The total yield for both cultivars, TropicBeauty and UFSharp, as response to different $\mathrm{N}$ treatment are presented in Table 1. The moderate $\mathrm{N}$ treatment resulted in highest yield as compared with 45 and $179 \mathrm{~kg} \cdot \mathrm{ha}^{-1}$ per year $\mathrm{N}$ treatment. The TSS, TA, and RI for both cultivars, TropicBeauty and UFSharp, are presented in Table 2. The RI for both 'TropicBeauty' and 'UFSharp' in all N treatments were not significantly different $(P>0.05)$ suggesting that the fruit were at a similar ripening stage across the treatments and cultivars. In 'TropicBeauty', $\mathrm{N}$ treatments did not affect TSS; however, in 'UFSharp', both low and moderate $\mathrm{N}$ supply, 0 and $90 \mathrm{~kg} \cdot \mathrm{ha}^{-1}$ per year, resulted in higher TSS content, whereas high rates of 179 and $269 \mathrm{~kg} \cdot \mathrm{ha}^{-1}$ per year resulted in $\approx 40 \%$ lower TSS. TA
Table 1. Total yield for fruit of subtropical peach cultivars, TropicBeauty and UFSharp, grown under five different nitrogen treatments in 2014.

\begin{tabular}{llc}
\hline $\begin{array}{l}\mathrm{N} \text { treatment } \\
\left(\mathrm{kg} \cdot \mathrm{ha}^{-1} \text { per } \mathrm{yr}\right)\end{array}$ & \multicolumn{2}{c}{ Total yield $\left[\mathrm{mean}^{\mathrm{z}} \pm \mathrm{SD}(\mathrm{kg})\right]$} \\
\cline { 2 - 3 } & TropicBeauty & UFSharp \\
\hline 0 & $3.05 \pm 2.5 \mathrm{AB}$ & $3.15 \pm 2.6 \mathrm{AB}$ \\
90 & $2.61 \pm 2.8 \mathrm{~B}$ & $2.62 \pm 3.0 \mathrm{~B}$ \\
179 & $3.63 \pm 1.9 \mathrm{~A}$ & $4.26 \pm 3.5 \mathrm{~A}$ \\
269 & $2.64 \pm 2.2 \mathrm{~B}$ & $2.23 \pm 1.9 \mathrm{~B}$ \\
& $2.84 \pm 1.6 \mathrm{AB}$ & $3.45 \pm 3.3 \mathrm{AB}$
\end{tabular}

${ }^{\mathrm{z}}$ Means followed by uppercase letters indicate statistically significant differences between $\mathrm{N}$ rates within a cultivar using Tukey's honest significance test (HSD) at $\alpha=0.05$.

was significantly higher $(P<0.05)$ overall in 'UFSharp' than 'TropicBeauty'; however, there was no effect of $\mathrm{N}$ treatment. The average citric acid concentration in 'TropicBeauty' and 'UFSharp' was $1.4 \mathrm{mg} \cdot \mathrm{mL}^{-1}$ and $1.6 \mathrm{mg} \cdot \mathrm{mL}^{-1}$, respectively. A significant interaction between cultivar and $\mathrm{N}$ treatment $[\mathrm{C} \times \mathrm{N}$ $(P=0.043)]$ was found for citric acid quantification (Table 3$)$. In 'UFSharp', citric acid concentration was affected by the $\mathrm{N}$ treatment with the lowest citric acid concentration found in the absence of $\mathrm{N}$ [negative control $\left(0 \mathrm{~kg} \cdot \mathrm{ha}^{-1}\right.$ per year $)$ ]. In 'TropicBeauty', citric acid content did not change as a result of $\mathrm{N}$ treatment. Malic acid content was significantly lower in 'TropicBeauty' than in 'UFSharp' $(P=0.004)$. The average malic acid in 'TropicBeauty' and 'UFSharp' was 4.1 and $4.7 \mathrm{mg} \cdot \mathrm{mL}^{-1}$, respectively (Table 3 ). Malic acid content was found to be unaffected by $\mathrm{N}$ treatment in both the cultivars.

Both cultivars had significantly higher phenolic content in low $\mathrm{N}$ rates, and as the rate of $\mathrm{N}$ increased, phenolic content decreased (Fig. 1). An approximate 100\% increase in phenolic content occurred in trees not receiving $\mathrm{N}\left(0 \mathrm{~kg} \cdot \mathrm{ha}^{-1}\right.$ per year $)$ as compared with the highest $\mathrm{N}$ rate treatment, $269 \mathrm{~kg} \cdot \mathrm{ha}^{-1}$ per year, in 'TropicBeauty'. Similarly, in 'UFSharp', the highest phenolic content was observed in fruit from trees receiving $45 \mathrm{~kg} \cdot \mathrm{ha}^{-1}$ per year as compared with $269 \mathrm{~kg} \cdot \mathrm{ha}^{-1}$ per year, with a difference of $\approx 60 \%$ between the two rates. The phenolic content was found to be linearly dependent on the rate of $\mathrm{N}$ for both 'TropicBeauty' $\left[P<0.001, R^{2}\right.$ value 0.90 (Fig. 2)] and 'UFSharp' $(P=0.013)$. A significant interaction between cultivar and $\mathrm{N}$ treatment was observed $(\mathrm{C} \times \mathrm{N}, P=0.012)$, suggesting that the $\mathrm{N}$ treatment effect was dependent on the cultivar. For example, phenolic content was greatly reduced with high $\mathrm{N}$ rate treatment in 'TropicBeauty' as compared with 'UFSharp' (Fig. 1). As expected, flavonoid content in 'TropicBeauty' and 'UFSharp' followed a similar trend as phenolic content, with lower $\mathrm{N}$ rates resulting in higher flavonoid content (Fig. 3). Phenolic content and flavonoid content were linearly correlated with $R^{2}$ values of 0.82 and 0.73 (data not shown) for 'TropicBeauty' and 'UFSharp', respectively. Similar to phenolic content, an increase of more than $200 \%$ in flavonoid content was observed in trees receiving no $\mathrm{N}\left(0 \mathrm{~kg} \cdot \mathrm{ha}^{-1}\right.$ per year) compared with $269 \mathrm{~kg} \cdot \mathrm{ha}^{-1}$ per year in 'TropicBeauty'. A significant interaction between cultivars and $\mathrm{N}$ treatments $(\mathrm{C} \times \mathrm{N}, P=0.009)$ was also observed; increasing $\mathrm{N}$ rate decreased the flavonoid content greater in 'TropicBeauty' than in 'UFSharp'. No significant $\mathrm{N}$ rate and cultivar interaction was observed for anthocyanin (Fig. 4). Overall, anthocyanin content in 'TropicBeauty' was significantly higher $(P<0.001)$ than 'UFSharp' irrespective of $\mathrm{N}$ treatment. 
Table 2. Total soluble solids (TSS), titratable acidity (TA), and ripening index (RI) for fruit of subtropical peach cultivars, TropicBeauty and UFSharp, grown under five different nitrogen treatments.

\begin{tabular}{|c|c|c|c|c|c|c|}
\hline \multirow{2}{*}{$\begin{array}{l}\mathrm{N} \text { treatment } \\
\left(\mathrm{kg} \cdot \mathrm{ha}^{-1} \text { per } \mathrm{yr}\right)\end{array}$} & \multicolumn{2}{|c|}{ TSS $\left[\operatorname{mean}^{z} \pm\right.$ SD $\left.(\%)\right]$} & \multicolumn{2}{|c|}{ TA $\left[\operatorname{mean}^{z} \pm\right.$ SD $(\%$ malic acid $\left.)\right]$} & \multicolumn{2}{|c|}{$\mathrm{RI}^{\mathrm{y}}\left(\mathrm{mean}^{\mathrm{z}} \pm \mathrm{SD}\right)$} \\
\hline & TropicBeauty & UFSharp & TropicBeauty & UFSharp & TropicBeauty & UFSharp \\
\hline 0 & $12.20 \pm 1.80 \mathrm{bA}$ & $19.30 \pm 6.85 \mathrm{aAB}$ & $0.55 \pm 0.05$ & $0.72 \pm 0.45$ & $21.98 \pm 1.46$ & $31.77 \pm 17.04$ \\
\hline 45 & $16.43 \pm 7.74 \mathrm{aA}$ & $11.88 \pm 5.59 \mathrm{aC}$ & $0.55 \pm 0.03$ & $0.80 \pm 0.10$ & $30.15 \pm 14.51$ & $15.73 \pm 10.01$ \\
\hline 179 & $11.55 \pm 0.79 \mathrm{aA}$ & $14.23 \pm 3.45 \mathrm{aBC}$ & $0.52 \pm 0.02$ & $0.65 \pm 0.18$ & $22.41 \pm 1.96$ & $22.14 \pm 1.96$ \\
\hline 269 & $12.73 \pm 1.16 \mathrm{aA}$ & $12.75 \pm 3.95 \mathrm{aC}$ & $0.68 \pm 0.16$ & $0.72 \pm 0.12$ & $19.18 \pm 2.62$ & $17.75 \pm 5.38$ \\
\hline
\end{tabular}

${ }^{\mathrm{z}}$ Means followed by different lowercase letters indicate statistically significant differences between cultivars within an $\mathrm{N}$ rate $(P=0.05) ;$ means followed by uppercase letters indicate statistically significant differences between $\mathrm{N}$ rates within a cultivar $(P=0.05)$; means followed by no letter are not significantly different. Mean separation was performed using Tukey's honest significance test (HSD) at $\alpha=0.05$.

${ }^{\mathrm{y}}$ Ripening index is calculated as TSS/TA.

Table 3. Citric and malic acid levels for fruit of subtropical peach cultivars, TropicBeauty and UFSharp, from trees grown under five different nitrogen treatments.

\begin{tabular}{lccc}
\hline $\begin{array}{l}N \text { treatment } \\
\left(\mathrm{kg} \cdot \mathrm{ha}^{-1} \text { per } \mathrm{yr}\right)\end{array}$ & \multicolumn{2}{c}{ Citric acid $\left[\mathrm{mean}^{\mathrm{z}} \pm \mathrm{SD}\left(\mathrm{mg} \cdot \mathrm{mL}^{-1}\right)\right]$} & \multicolumn{2}{c}{${\text { Malic acid }\left[\mathrm{mean}^{\mathrm{z}} \pm \mathrm{SD}\left(\mathrm{mg} \cdot \mathrm{mL}^{-1}\right)\right]}^{\text {TropicBeauty }}$} & UFSharp & TropicBeauty \\
\hline 0 & $1.4 \pm 0.24$ & $1.02 \pm 0.17 \mathrm{~B}$ & $4.65 \pm 0.38$ \\
45 & $1.6 \pm 0.43$ & $1.52 \pm 0.45 \mathrm{AB}$ & $4.22 \pm 0.75$ \\
90 & $1.5 \pm 0.14$ & $1.77 \pm 0.45 \mathrm{~A}$ & $3.8 \pm 0.35$ \\
179 & $1.27 \pm 0.25 \mathrm{~b}$ & $2.02 \pm 0.35 \mathrm{aA}$ & $4.1 \pm 1.20$ \\
269 & $1.27 \pm 0.52$ & $1.65 \pm 0.25 \mathrm{AB}$ & $3.57 \pm 0.56$ \\
\hline
\end{tabular}

${ }^{\mathrm{z}}$ Means followed by different lowercase letters indicate statistically significant differences between cultivars within an N rate; means followed by uppercase letters indicate statistically significant differences between $\mathrm{N}$ rates within a cultivar; means followed by no letter are not significantly different. Mean separation was performed using Tukey's honest significance test (HSD) at $\alpha=0.05$.

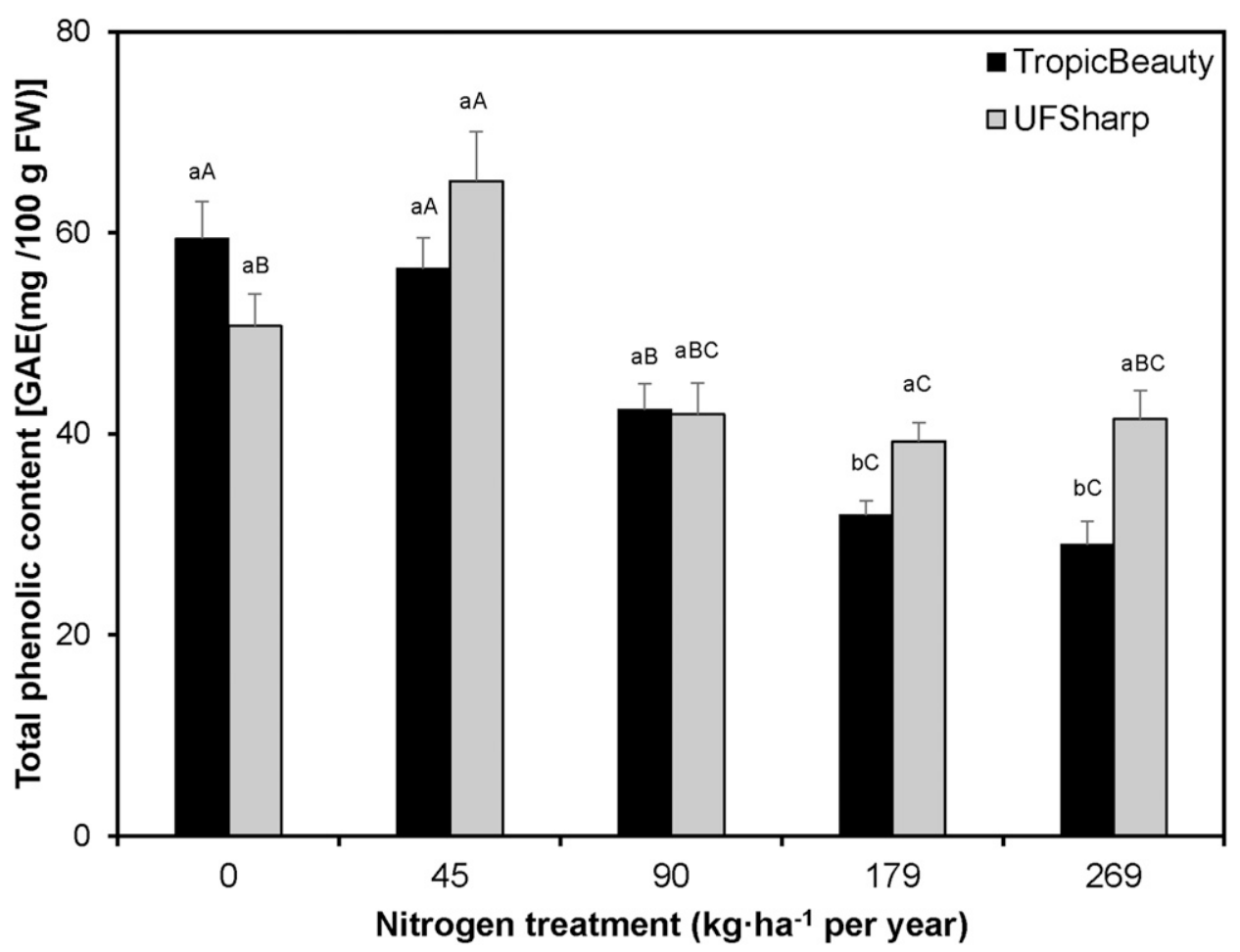

Fig. 1. Total phenolic content (mean $\pm \mathrm{SE}$ ), expressed as gallic acid equivalents (GAE) for subtropical peach cultivars, TropicBeauty and UFSharp, grown under five different nitrogen treatments. Lowercase letters indicate statistically significant differences between the two cultivars within an $\mathrm{N}$ treatment; uppercase letters indicate statistically significant differences between $\mathrm{N}$ treatments within a cultivar. Mean separation was performed using Tukey's honest significance test (HSD) at $\alpha=0.05$.

The overall antioxidant activity was significantly higher in 'UFSharp' than in 'TropicBeauty' $[P=0.026$ (Fig. 5) $]$. As the $\mathrm{N}$ rate increased, a decrease in antioxidant activity was observed in 'TropicBeauty', with a similar trend in 'UFSharp'. The antioxidant activity followed similar trends to phenolic content and flavonoid content and a significant linear relationship between antioxidant capacity and phenolic content was found in 'TropicBeauty' and 'UFSharp' $\left[R^{2}\right.$ $=0.95$ and 0.52 , respectively (data not shown)]. A significant interaction between cultivars and $\mathrm{N}$ treatment $(\mathrm{C} \times \mathrm{N}, P=0.03)$ indicated that cultivar played a critical factor in effect of $\mathrm{N}$ treatment. For example, 'TropicBeauty' had a more pronounced decrease in antioxidant activity as the $\mathrm{N}$ treatment increased in comparison with 'UFSharp'.

EXPERIMENT 2. The average yield in response to different $\mathrm{N}$ treatment varied. Moderate N (90 and 179 $\mathrm{kg} \cdot \mathrm{ha}^{-1}$ per year) treatment resulted in highest yield, whereas 40 and 269 $\mathrm{kg} \cdot \mathrm{ha}^{-1}$ per year $\mathrm{N}$ treatment resulted in lowest yield (data not shown). No significant differences were observed in yield at different harvest times. No significant difference in TSS content as influenced by harvest dates and $\mathrm{N}$ treatments were observed $(P>0.05)$, although an increasing trend in the average TSS on each harvest date was noticed (Table 4). No significant differences were observed in TA among harvest date and $\mathrm{N}$ treatment $[P>0.05$ (Table 4$)]$. A 


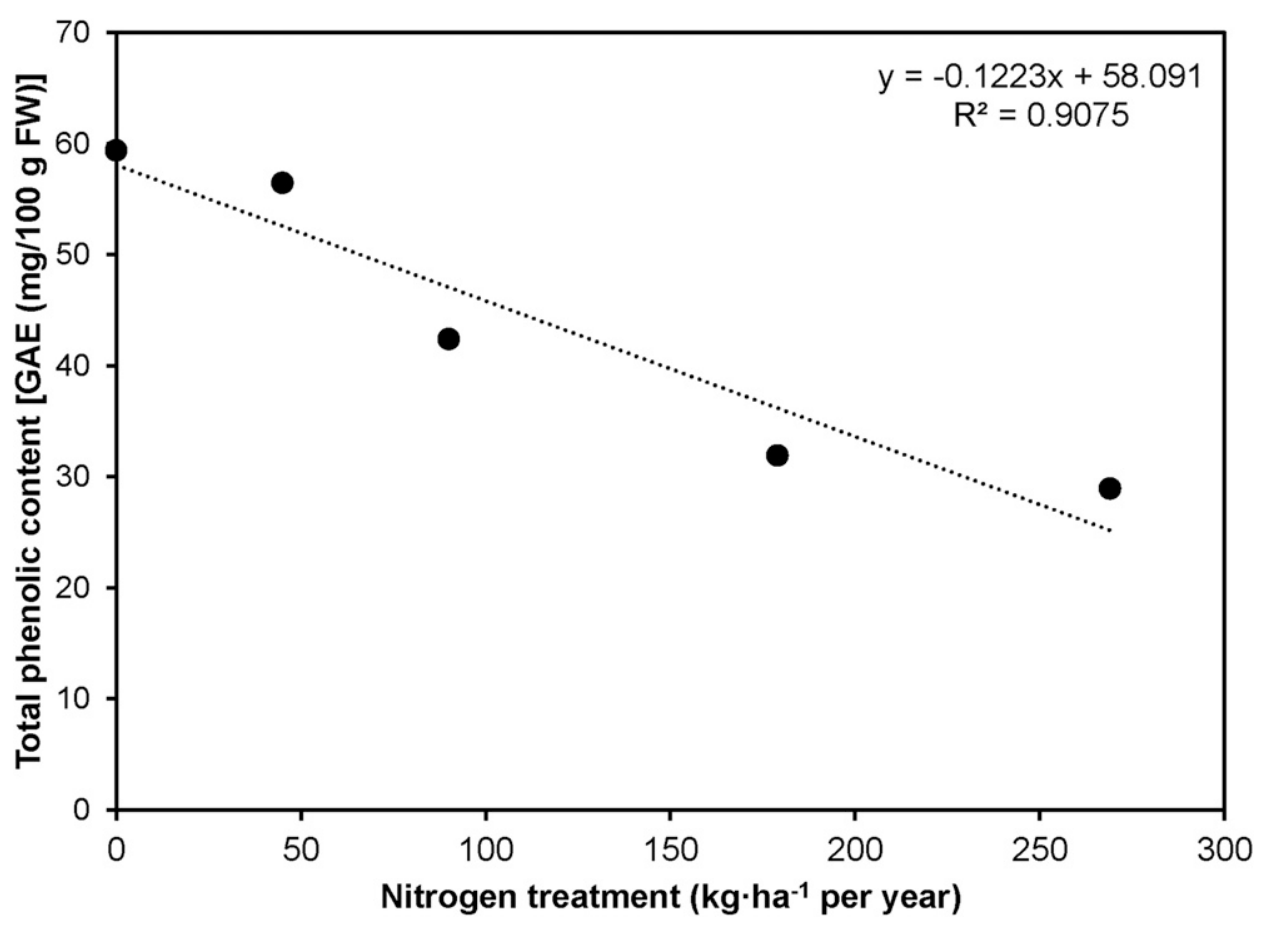

Fig. 2. Correlation between total phenolic content, expressed as gallic acid equivalent (GAE) and rate of nitrogen fertilization in subtropical peach cultivar, TropicBeauty.

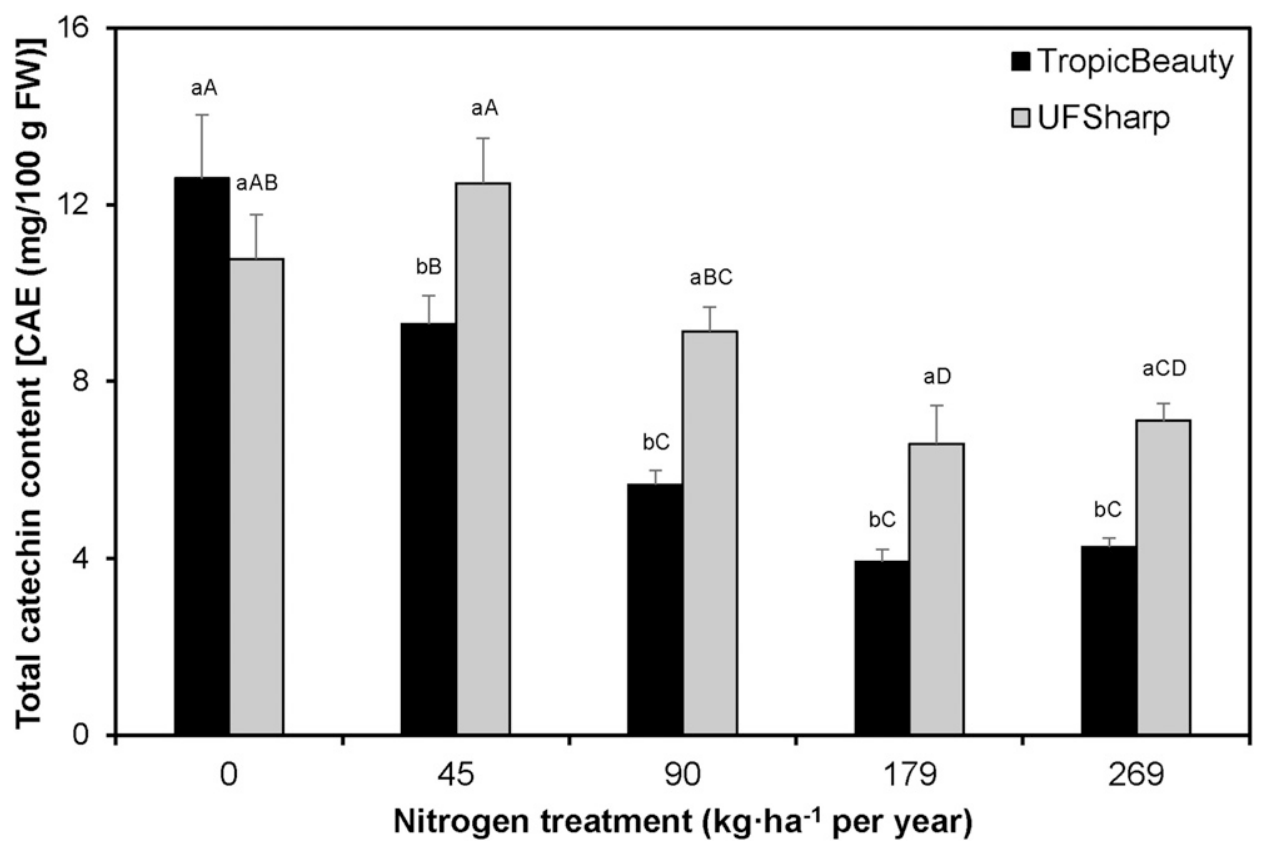

Fig. 3. Total flavonoid content (mean $\pm \mathrm{SE}$ ), expressed as catechin equivalents (CAE) for subtropical peach cultivars, TropicBeauty and UFSharp, grown under five different nitrogen treatments. Lowercase letters indicate statistically significant differences between the two cultivars within an $\mathrm{N}$ treatment; uppercase letters indicate statistically significant differences between $\mathrm{N}$ treatments within a cultivar. Mean separation was performed using Tukey's honest significance test (HSD) at $\alpha=0.05$.

significant decrease $(P<0.05)$ in TA from early to late harvest was observed. No significant interaction for harvest time and $\mathrm{N}$ treatment was found for $\mathrm{RI}(P>0.05)$. As expected, a significant increase in ripening index was observed from early to late harvest $[P<0.001$ (Table 4)]. Similar to TA, average citric acid content was observed to be significantly different $[P<0.001$
(Table 5)] at each harvest date, although no interaction was observed between harvest date and $\mathrm{N}$ treatment $(P>0.05)$. No effects in malic acid content were observed because of harvest time or $\mathrm{N}$ treatment $[P>0.05$ (Table 5)].

A significant interaction between harvest date and $\mathrm{N}$ treatment for phenolic content $[\mathrm{H} \times \mathrm{N}, P<$ 0.001 (Table 6)] was observed. Total phenolic content among all three harvest dates and $\mathrm{N}$ treatments was found to be significantly different $(P<0.001)$ with an exception of treatment $179 \mathrm{~kg} \cdot \mathrm{ha}^{-1}$ per year and an overall trend of reduced phenolic content with later harvests. Total flavonoid content followed a similar trend as phenolic content. A significant correlation between flavonoid content and phenolic content was observed for all three harvest dates and $\mathrm{N}$ treatments (data not shown). A significant interaction among harvest date and $\mathrm{N}$ treatment for flavonoid content was observed $[P<$ 0.001 (Table 6)]. Overall, flavonoid content decreased with advancement in harvest date. Significant differences among treatments in each harvest date were found, but overall no uniform trend was observed among different $\mathrm{N}$ rates. A significant increase in anthocyanin content was found with later harvest date, in addition to a significant interaction among harvest and $\mathrm{N}$ treatment $[P<$ 0.001 (Table 6)]. Total anthocyanin content was consistently high for all $\mathrm{N}$ treatments at the latest harvest date with a $40 \%$ increase in anthocyanin content as compared with the early harvest date. The effect of different levels of $\mathrm{N}$ was not clear on anthocyanin content.

In regard to antioxidant capacity, a significant interaction among harvest and $\mathrm{N}$ treatment was observed $[P=0.042$ (Table 6)]. Total antioxidant capacity in each harvest date was observed to be affected by the $\mathrm{N}$ treatment. Total antioxidant capacity was found to be the highest in early harvest, followed by mid and late harvests (Table 6). A significant linear relationship between antioxidant capacity and phenolic content was observed among all three harvest dates, $R$ was 0.82 $(P<0.001), 0.66(P=0.006)$, and $0.62(P=0.014)$ for early, mid, and late harvest, respectively.

Interestingly, in mid and late harvest dates for phenolic content, flavonoid content, and anthocyanin content, all harvest 


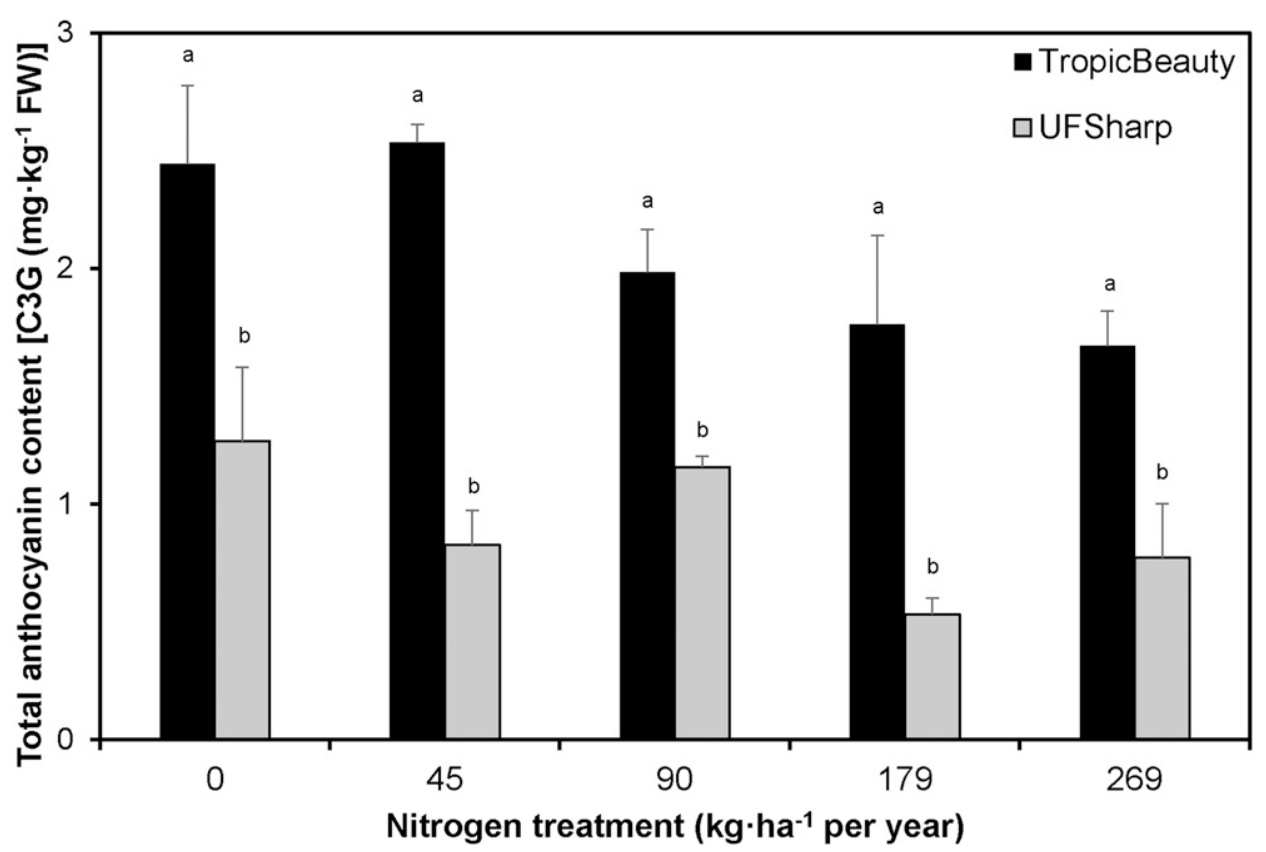

Fig. 4. Total anthocyanin content (mean $\pm \mathrm{SE}$ ), expressed as cyanidin-3-glucoside equivalents (C3GE) for subtropical peach cultivars, TropicBeauty and UFSharp, grown under five different nitrogen treatments. Lowercase letters indicate statistically significant differences between the two cultivars within an $\mathrm{N}$ treatment; uppercase letters indicate statistically significant differences between $\mathrm{N}$ treatments within a cultivar. Mean separation was performed using Tukey's honest significance test (HSD) at $\alpha=0.05$.

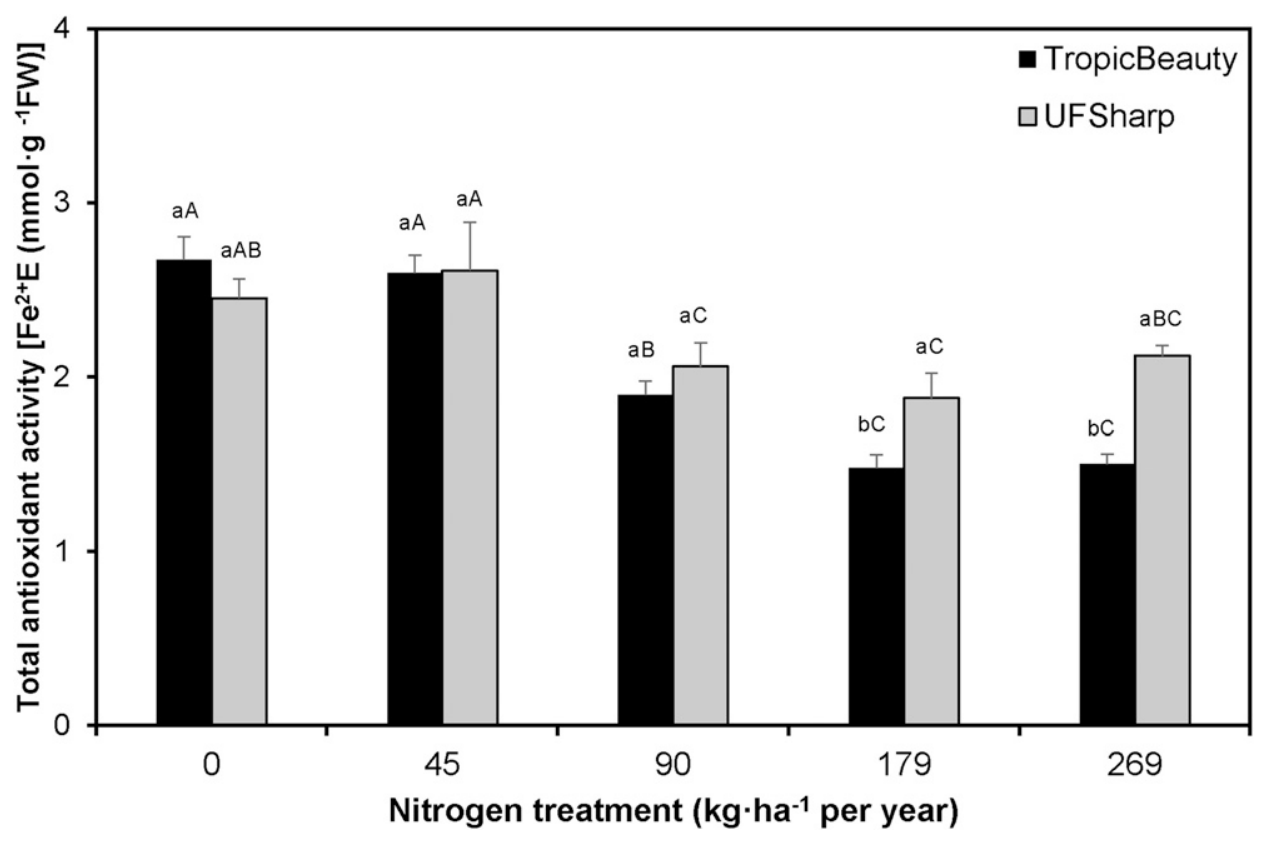

Fig. 5. Total antioxidant activity (mean $\pm \mathrm{SE}$ ), expressed as ferrous equivalents $\left(\mathrm{Fe}^{2+} \mathrm{E}\right)$ for subtropical peach cultivars, TropicBeauty and UFSharp, grown under five different nitrogen treatments. Lowercase letters indicate statistically significant differences between the two cultivars within an $\mathrm{N}$ treatment; uppercase letters indicate statistically significant differences between $\mathrm{N}$ treatments within a cultivar. Mean separation was performed using Tukey's honest significance test (HSD) at $\alpha=0.05$.

dates of antioxidant capacity of $0 \mathrm{~kg} \cdot \mathrm{ha}^{-1}$ per year and $269 \mathrm{~kg} \cdot \mathrm{ha}^{-1}$ per year $\mathrm{N}$ treatment were ranked among the highest, whereas most of the observations of $179 \mathrm{~kg} \cdot \mathrm{ha}^{-1}$ per year $\mathrm{N}$ treatment displayed the lowest values for phenolic content, flavonoid content, anthocyanin content, and antioxidant capacity. Therefore, no clear effect of $\mathrm{N}$ treatments on phytochemical content and antioxidant activity was clear in Expt. 2. Overall, late harvest resulted in lowest phenolic content, flavonoid content, and antioxidant capacity and highest anthocyanin content.

\section{Discussion}

Overall, subtropical peach trees responded to different $\mathrm{N}$ treatments; subtropical peach fruit quality and phytochemical composition was positively influenced with lower $\mathrm{N}$ rates. Average TA and organic acid content was higher in 'UFSharp' than 'TropicBeauty', although no effect of $\mathrm{N}$ treatment was found on TA or organic acid content for both cultivars. Inherent differences among 'TropicBeauty' and 'UFSharp' were evident suggesting that every genotype responds differently to abiotic conditions, and there is a possible genotype and mineral nutrient interaction which results in a differential response of two cultivars toward the same treatments. In both experiments, TSS in 'TropicBeauty' was unaffected by $\mathrm{N}$ treatments, whereas an overall inverse relationship was observed between TSS and N treatments. Similar to our results, an increase in TSS in tomato fruit with decreasing $\mathrm{N}$ rate has been reported previously (Simonne et al., 2007), and an increase of $5 \%$ to $17 \%$ in TSS with a concomitant decrease in TA was observed when $\mathrm{N}$ supply was reduced to half of the amount (Bénard et al., 2009). In addition, an increase in individual sugars (glucose, sucrose, and fructose) with a decrease in acids (citrate, isocitrate, fumarate, and malate) was found in tomato leaves when grown in N-deficient medium (UrbanczykWochniak and Fernie, 2005). Harvest date had little influence on subtropical peach fruit quality, increase in TSS content; a decreasing trend in TA was observed with advancement of harvest date. RI index for late harvest was observed to be significantly higher, suggesting progression of ripening of the fruit at late harvest time point.

A decrease in phenolic content and flavonoid content was observed with an increasing rate of $\mathrm{N}$ application, although this effect seemed to be more pronounced in 'TropicBeauty' than 'UFSharp' suggesting inherent cultivar differences and strong 


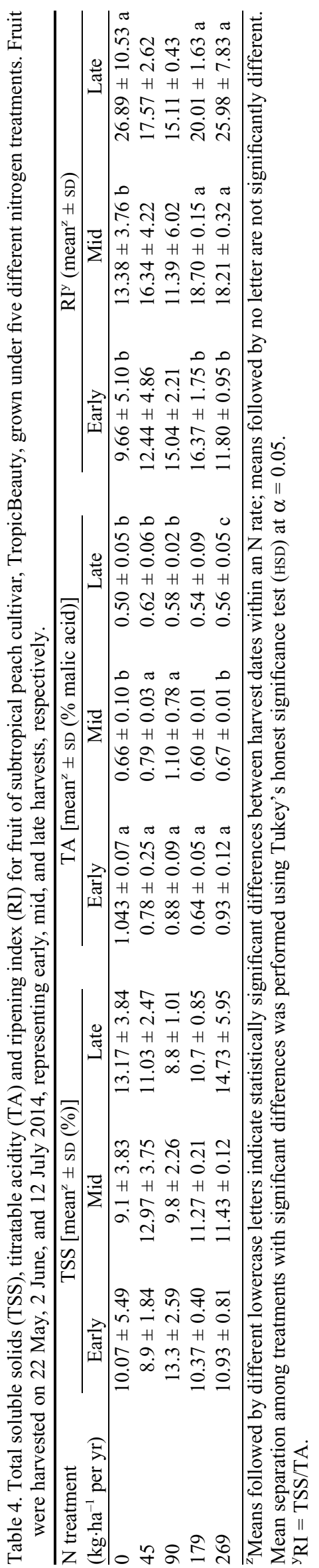

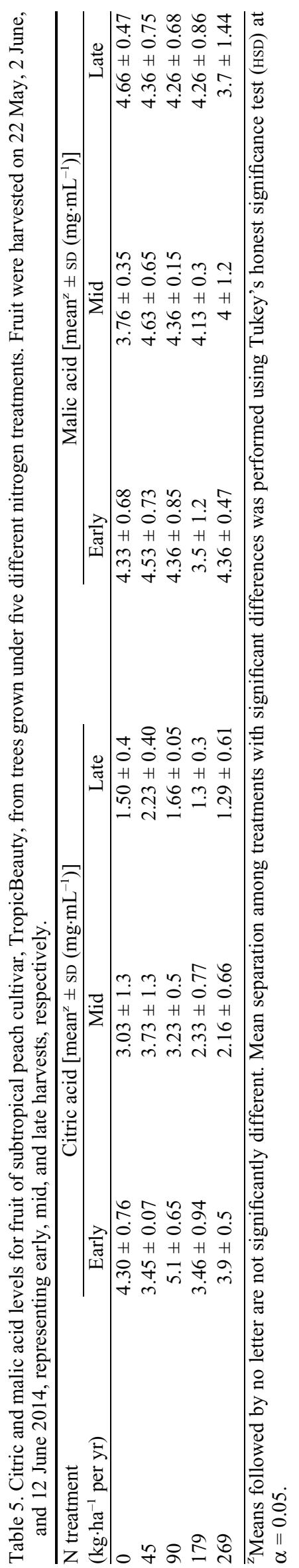




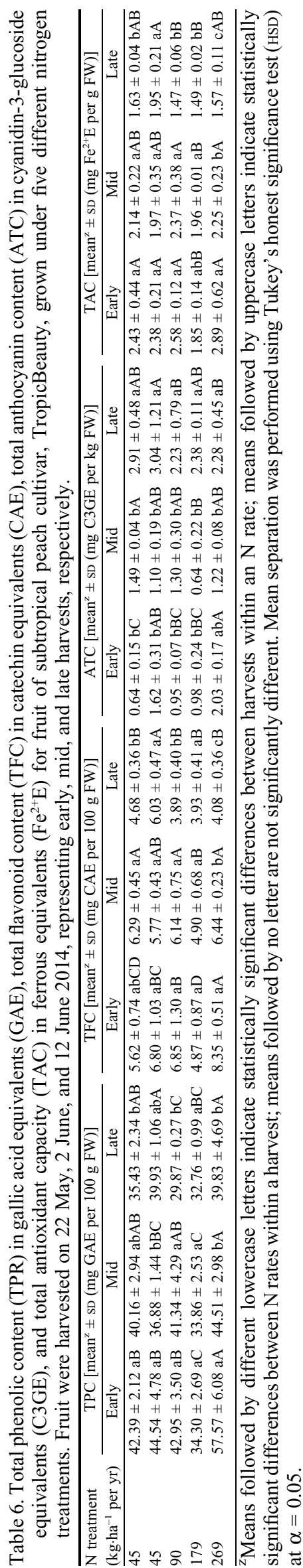

genetic $\times$ environment $(G \times E)$ interaction. As expected, flavonoid content followed a similar pattern to phenolic content. The phenolic content and flavonoid content of both cultivars were in agreement with the range of phenolic content and flavonoid content reported for subtropical peaches in other studies (Cantín et al., 2009; Font i Forcada et al., 2012). Cantín et al. (2009) compared several genotypes of subtropical peaches and among the cultivars used, the highest values of phenolic content observed were $\approx 30-60 \mathrm{mg}$ GAE per $100 \mathrm{~g} \mathrm{FW}$ and flavonoid content was 8-12 mg CAE per $100 \mathrm{~g} \mathrm{FW}$. A decrease in phenolic content and flavonoid content with increases in $\mathrm{N}$ application has been reported in a number of other crops like broccoli (Fortier et al., 2010), tomato (Bongue-Bartelsman and Phillips, 1995), and apple (Strissel et al., 2005). N depletion can stimulate the activation of the flavonoid pathway via a number of genes and enzymes, thereby increasing flavonoid content. More specifically, $\mathrm{N}$ deprivation greatly increased the levels of mRNA transcripts of critical enzymes required for flavonoid biosynthesis, chalcone synthase (CHS), and dihydroflavanol reductase (DFR) (Bongue-Bartelsman and Phillips, 1995; Stefanelli et al., 2010). Alternatively, $\mathrm{N}$ deficit effects photosynthesis by decreasing the available chlorophyll pigment and disrupting photosynthetic membranes because of starch accumulation, leading to increased sensitivity to high light levels. The production of photoprotective pigments such as flavonols and anthocyanins may provide protection against light-induced oxidative damage (Guidi et al., 1998). Flavonols are known to accumulate in the skins of tomato fruit (Stewart et al., 2000) and could, therefore, filter out damaging wavelengths of radiation. We also observed a decrease in phenolic content and flavonoid content with advancement in harvesting dates; such a decrease in phenolic content and flavonoid content can be potentially because of the changes in weather condition. As the harvest date progressed late in the season, the overcast and rainfall (as suggested by Florida Automated Weather Network, UF) increased which could have contributed to a decrease in phenolic content and flavonoid content. Polyphenolic compounds are reported to vary greatly among cultivars (Aaby et al., 2007; Tulipani et al., 2008), cultural systems, and environmental factors. Flavonoid accumulation can be induced by a number of environmental conditions, including ultraviolet light (WinkelShirley, 2002), pathogen attack (Dixon and Paiva, 1995), and nutrient deficiencies (Stewart et al., 2001). The lack of significant trends in phenolic content and flavonoid content observed in Expt. 2 might be due to the tree age; trees used in this experiment were mature, large, and well-established trees and, therefore, may not have been as influenced by different rates of $\mathrm{N}$ applied as younger trees (as in Expt. 1 where treatments were applied from the time of establishment). Anthocyanin content values were well in range of values reported in other subtropical peach studies (Cantín et al., 2009). Anthocyanin content in subtropical peaches is dependent on genetics as well as environmental factors; for example, Reig et al. (2013) reported as much as 11-fold changes in the anthocyanin content among different cultivars. Similar results were reported by Cantín et al. (2009) in subtropical peach and nectarine $(P$. persica) progenies. In Expt. 1, anthocyanin content in 'TropicBeauty' was higher than 'UFSharp' irrespective of $\mathrm{N}$ treatment suggesting cultivar differences. This is also supported by visual fruit observation and description; 'Tropic Beauty' develops about $70 \%$ blush at maturity, whereas the 'UF Sharp' develops up to $60 \%$ blush (Olmstead et al., 2013). 
Medium to low rates of $\mathrm{N}$ have been reported to result in higher concentration of anthocyanin in a number of fruit such as subtropical peaches (Cordts et al., 1987), grapes, and strawberries (Yoshida et al., 2003). In this present study, an increase in anthocyanin content was also observed at a later harvest date coinciding with previous studies in southern highbush blueberry (Prior et al., 1998), sour cherry [Prunus cerasus (Poll et al., 2003)], and apple (Reay and Lancaster, 2001). Overall, manipulation of $\mathrm{N}$ and harvest date can be used to stimulate increases in polyphenolic compounds that can increase the nutritional value in crops.

Many studies have reported a correlation of antioxidant activity with phenolic, flavonoid, and anthocyanin content in animals and humans. The correlation found between plasma endogenous antioxidant and circulating level of dietary phenolics have been shown in many fruit crops such as strawberry (Azzini et al., 2010) and blackberry [Rubus sp. (Srivastava et al., 2010)]. A significant and positive relationship was observed between antioxidant activity and phenolic content in both cultivars and harvest dates. A reduction in antioxidant capacity was observed with an increasing $\mathrm{N}$ rate in 'TropicBeauty' and 'UFSharp', but no consistent differences in $\mathrm{N}$ treatments were observed in different harvests, although antioxidant capacity decreased at later harvest date. Similar data were also reported in subtropical peaches and nectarines (Font i Forcada et al., 2012; Gil et al., 2002), apples (Lata, 2007), sweet cherries [Prunus avium (Serrano et al., 2005)], and plums (Gil et al., 2002).

\section{Conclusion}

Overall, differences in phenolic content, flavonoid content, anthocyanin content, and antioxidant capacity were observed among different rates of $\mathrm{N}$ in subtropical peach cultivars, TropicBeauty (melting flesh) and UFSharp (nonmelting flesh). The differences in phytochemical content and antioxidant activity between early, mid, and late harvest dates were also observed but no consistent trends or patterns were observed in $\mathrm{N}$ treatments in Expt. 2. Experiment 1 was conducted in a young orchard with the treatments applied since establishment, which could have resulted in differences among treatments being more pronounced. Experiment 2 was conducted in a mature orchard and treatments were applied for the last 3 years, which could have potentially contributed to such results as before the application of treatments all trees were receiving the same rate of N. Overall, these data suggest that the concentration of health benefiting compounds such as polyphenolics and antioxidants can be altered with cultural practices such as fertilization and harvest maturity. Manipulations to cultural practices such as reduced $\mathrm{N}$ fertilization or early harvest can be easily done without any added cost to obtain fruit with higher health benefits, and thus, provide consumers an added advantage with consumption of fresh subtropical peaches.

\section{Literature Cited}

Aaby, K., D. Ekeberg, and G. Skrede. 2007. Characterization of phenolic compounds in strawberry (Fragaria $\times$ ananassa) fruit by different HPLC detectors and contribution of individual compounds to total antioxidant capacity. J. Agr. Food Chem. 55:4395-4406.

Ames, B.N., M.K. Shigenaga, and T.M. Hagen. 1993. Oxidants, antioxidants, and the degenerative diseases of aging. Proc. Natl. Acad. Sci. USA 90:7915-7922.
Anttonen, M.J., K.I. Hoppula, R. Nestby, M.J. Verheul, and R.O. Karjalainen. 2006. Influence of fertilization, mulch color, early forcing, fruit order, planting date, shading, growing environment, and genotype on the contents of selected phenolics in strawberry (Fragaria $\times$ ananassa Duch.) fruits. J. Agr. Food Chem. 54:26142620.

Atkinson, C.J., P.A.A. Dodds, Y.Y. Ford, J. Le Miere, J.M. Taylor, P.S. Blake, and N. Paul. 2006. Effects of cultivar, fruit number and reflected photosynthetically active radiation on Fragaria $\times$ ananassa productivity and fruit ellagic acid and ascorbic acid concentrations. Ann. Bot. 97:429-441.

Azzini, E., F. Intorre, P. Vitaglione, A. Napolitano, M.S. Foddai, A. Durazzo, A. Fumagalli, G. Catasta, L. Rossi, E. Venneria, M.F. Testa, A. Raguzzini, L. Palomba, V. Fogliano, and G. Maiani. 2010. Absorption of strawberry phytochemicals and antioxidant status changes in humans. J. Berry Res. 1:81-99.

Bavaresco, L., S. Pezzutto, A. Ragga, F. Ferrari, and M. Trevisan. 2001. Effect of nitrogen supply on transresveratrol concentration in berries of Vitis vinifera L. cv. Cabernet Sauvignon. Vitis 40:229-230.

Bénard, C., H. Gautier, F. Bourgaud, D. Grasselly, B. Navez, and C. Caris-Veyrat. 2009. Effects of low nitrogen supply on tomato (Solanum lycopersicum) fruit yield and quality with special emphasis on sugars, acids, ascorbate, carotenoids and phenolic compounds. J. Agr. Food Chem. 57:4112-4123.

Benoit, L.F. and A.M. Berry. 1997. Flavonoid-like compounds from seeds of red alder (Alnus rubra) influence host nodulation by Frankia (Actinomycetales). Physiol. Plant. 99:588-593.

Benzie, I.F.F. and Y.T. Szeto. 1999. Total antioxidant capacity of teas by the ferric reducing/antioxidant power assay. J. Agr. Food Chem. 47:633-636.

Berhow, M.A. and S.F. Vaughn. 1999. Higher plant flavonoids: Biosynthesis and chemical ecology, p. 423-438. In: S. Inderjit, K.M.M. Dakshini, and C.L. Foy (eds.). Principles and practices in plant ecology. CRC Press, Boca Raton, FL.

Bongue-Bartelsman, M. and D.A. Phillips. 1995. Nitrogen stress regulates gene expression of enzymes in the flavonoid biosynthetic pathway of tomato. Plant Physiol. Biochem. 33:539-546.

Brignolas, F., F. Lieutier, D. Sauvard, E. Christiansen, and A.A. Berryman. 1998. Phenolic predictors for Norway spruce resistance to the bark beetle Ips typographus (Coleoptera: Scolytidae) and an associated fungus, Ceratocystis polonica. Can. J. For. Res. 28:720728.

Buendia, B., M.I. Gil, J.A. Tudela, A.L. Gady, J.J. Medina, C. Soria, J. M. Lopez, and F.A. Tomas-Barberan. 2010. HPLC-MS analysis of proanthocyanin oligomers and other phenolics in 15 strawberry cultivars. J. Agr. Food Chem. 58:3916-3926.

Burda, S., W. Oleszek, and C.Y. Lee. 1990. Phenolic compounds and their changes in apples during maturation and cold storage. J. Agr. Food Chem. 38:945-948.

Byrne, D.H. and T.A. Bacon. 1999. Founding clones of low-chill fresh market peach germplasm. Fruit Var. J. 53:162-171.

Cantín, C., M.A. Moreno, and Y. Gogorcena. 2009. Evaluation of the antioxidant capacity, phenolic compounds, and vitamin $\mathrm{C}$ content of different peach and nectarine (Prunus persica (L.) Batsch) breeding progenies. J. Agr. Food Chem. 57:4586-4592.

Colaric, M., R. Veberic, A. Solar, M. Hudina, and F. Stampar. 2005. Phenolic acids, syringaldehyde, and juglone in fruits of different cultivars of Juglans regia L. J. Agr. Food Chem. 53:6390-6396.

Cordts, J.M., R. Scorza, and R. Bell. 1987. Effects of carbohydrates and nitrogen on the development of anthocyanins of a red leaf peach (Prunus persica (L.) Batsch) in vitro. Plant Cell Tissue Organ Cult. 9:103-110.

Coria-Cayupan, Y.S., M.I. Sanchez de Pinto, and M.A. Nazareno. 2009. Variations in bioactive substance contents and crop yields of lettuce (Lactuca sativa L.) cultivated in soils with different fertilization treatments. J. Agr. Food Chem. 57:10122-10129.

Crisosto, C.H. and D. Valero. 2008. Harvesting and postharvest handling of peaches for the fresh market, p. 575-596. In: D.R. Layne 
and D. Bassi (eds.). The peach: Botany, production and uses. CAB Intl., Wallingford, UK.

De Freitas, V.A. and Y. Glories. 1999. Concentration and compositional changes of procyanidins in grape seeds and skin of white Vitis vinifera varieties. J. Sci. Food Agr. 79:1601-1606.

Delgado, C., G.M. Crisosto, H. Heymann, and C.H. Crisosto. 2013. Determining the primary drivers of liking to predict consumers' acceptance of fresh nectarines and peaches. J. Food Sci. 78:S605-S614.

Dixon, R.A. and N.L. Paiva. 1995. Stress-induced phenylpropanoid metabolism. Plant Cell 7:1085-1097.

Donovan, J.L., A.S. Meyer, and A.L. Waterhouse. 1998. Phenolic composition and antioxidant activity of prunes and prune juice (Prunus domestica). J. Agr. Food Chem. 46:1247-1252.

Fernandez-Escobar, R., G. Beltran, M.A. Sanchez-Zamora, J. GarciaNovelo, M.P. Aguilera, and M. Uceda. 2006. Olive oil quality decreases with nitrogen over-fertilization. HortScience 41:215-219.

Font i Forcada, C., Y. Gogorcena, and M.A. Moreno. 2012. Agronomical and fruit quality traits of two peach cultivars on peachalmond hybrid rootstocks growing on Mediterranean conditions. Sci. Hort. 140:157-163.

Fortier, E., Y. Desjardins, N. Tremblay, C. Belec, and M. Cote. 2010. Influence of irrigation and nitrogen fertilization on broccoli polyphenolics concentration. Acta Hort. 856:55-62.

Fukumoto, L.R. and G. Mazza. 2000. Assessing antioxidant and prooxidant activities of phenolic compounds. J. Agr. Food Chem. 48:3597-3604.

Gil, M.I., F.A. Tomas-Barberan, B. Hess-Pierce, and A.A. Kader. 2002. Antioxidant capacities, phenolic compounds, carotenoids, and vitamin $\mathrm{C}$ contents of nectarine, peach, and plum cultivars from California. J. Agr. Food Chem. 50:4976-4982.

Gilbert, J.L., J.W. Olmstead, T.A. Colquhoun, L.A. Levin, D.G. Clark, and H.R. Moskowitz. 2014. Consumer-assisted selection of blueberry fruit quality traits. HortScience 49:864-873.

Guerra, M. and P.A. Casquero. 2008. Effect of harvest date on cold storage and postharvest quality of plum cv. Green Gage. Postharvest Biol. Technol. 47:325-332.

Guidi, L., G. Lorefice, A. Pardossi, F. Malorgio, F. Tognoni, and G.F. Soldatini. 1998. Growth and photosynthesis of Lycopersicon esculentum (L.) plants as affected by nitrogen deficiency. Biol. Plant. 40:235-244.

Harman, D. 1981. The aging process. Proc. Natl. Acad. Sci. USA 78:7124-7128.

Hilbert, G., J.P. Soyer, C. Molot, J. Giraudon, S. Milin, and J.P. Gaudillere. 2003. Effect of nitrogen supply on must quality and anthocyanin accumulation in berries of cv. Merlot. Vitis 42:69-76.

Hough, D.F. and L.F. Bonetti. 1988. Low chilling and disease resistance as main objectives of apple breeding in Santa Catarina, Brazil. Acta Hort. 232:15-25.

Hudina, M. and F. Stampar. 2000. Sugars and organic acids contents of European (Pyrus communis L.) and Asian (Pyrus serotina REHD.) pear cultivars. Acta Aliment. 29:217-230.

Jones, R.B., M. Imsic, P. Franz, and B.T. Tomkins. 2007. High nitrogen during growth reduced glucoraphanin and flavonol content in broccoli (Brassica oleracea var. italica) heads. Austral. J. Expt. Agr. 47:1498-1505.

Jovanovic, S.V., I. Jankovic, and L. Josimovic. 1992. Electron-transfer reactions of alkyl peroxy radicals. J. Amer. Chem. Soc. 114:9018-9021.

Kalt, W., C.F. Forney, A. Martin, and R.L. Prior. 1999. Antioxidant capacity, vitamin C, phenolics, and anthocyanins after fresh storage of small fruits. J. Agr. Food Chem. 47:4638-4644.

Keller, M. and G. Hrazdina. 1998. Interaction of N availability during bloom and light intensity during veraison. II. Effects on anthocyanin and phenolic development during grape ripening. Amer. J. Enol. Viticult. 49:341-349.

Kim, Y.C., K.S. Koh, and J.S. Koh. 2001. Changes of flavonoids in the peel of Jeju native citrus fruits during maturation. Food Sci. Biotechnol. 10:483-487.
Ko, S.H., S.W. Choi, S.K. Ye, B.L. Cho, H.S. Kim, and M.H. Chung. 2005. Comparison of the antioxidant activities of nine different fruits in human plasma. J. Med. Food 8:41-46.

Lata, B. 2007. Relationship between apple peel and the whole fruit antioxidant content: Year and cultivar variation. J. Agr. Food Chem. 55:663-671.

Lee, C.Y. and A. Jaworski. 1987. Phenolic compounds in white grapes grown in New York. Amer. J. Enol. Viticult. 38:277-281.

Lee, J., R.W. Durst, and R.E. Wrolstad. 2005. Determination of total monomeric anthocyanin pigment content of fruit juices, beverages, natural colorants, and wines by the $\mathrm{pH}$ differential method: Collaborative study. J. AOAC Intl. 88:1269-1278.

Lyrene, P.M. 2005. Breeding low-chill blueberries and peaches for subtropical areas. HortScience 40:1947-1949.

Malusà, E., E. Laurenti, E. Ghibaudi, and L. Rolle. 2004. Influence of organic and conventional management on yield and composition of grape cv. 'Grignolino'. Acta Hort. 640:135-141.

Morgan, K. and M. Olmstead. 2013. A diversification strategy for perennial crops in Florida. HortTechnology 23:482-489.

Murphy, A., W.A. Peer, and L. Taiz. 2000. Regulation of auxin transport by aminopeptidases and endogenous flavonoids. Planta 211:315-324.

Nava, G., A.R. Dechen, and G.R. Nachtigall. 2008. Nitrogen and potassium fertilization affect apple fruit quality in southern Brazil. Commun. Soil Sci. Plant Anal. 39:96-107.

Nguyen, P.M. and E.D. Niemeyer. 2008. Effects of nitrogen fertilization on the phenolic composition and antioxidant properties of basil (Ocimum basilicum L.). J. Agr. Food Chem. 56:8685-8691.

Olmstead, M.A., J. Chaparro, J.G. Williamson, R. Rouse, R. Mizell, P. Harmon, and J. Ferguson. 2013. Florida subtropical peaches: Production practices. Univ. Florida Inst. Food Agr. Sci. Ext. Publ. HS1109.

Olmstead, M.A., J. Gilbert, T. Colquhoun, D.G. Clark, and C. Sims. 2015. In pursuit of the perfect peach: Consumer-assisted selection of peach fruit traits. HortScience 50:1202-1212.

Poll, L., M. Petersen, and G.S. Nielsen. 2003. Influence of harvest year and harvest time on soluble solids, titratable acid, anthocyanin content and aroma components in sour cherry (Prunus cerasus L. cv. 'Stevnsbær'). Eur. Food Res. Technol. 216:212-216.

Predieri, S., P. Ragazzini, and R. Rondelli. 2006. Sensory evaluation and peach fruit quality. Acta Hort. 713:429-434.

Prior, R.L. and G.H. Cao. 2000. Antioxidant phytochemicals in fruits and vegetables: Diet and health implications. HortScience 35:588592.

Prior, R.L., G.H. Cao, A. Martin, E. Sofic, J. Mcewen, and C. O’Brien. 1998. Antioxidant capacity as influenced by total phenolic and anthocyanin content, maturity, and variety of vaccinium species. J. Agr. Food Chem. 46:2686-2693.

Prior, R.L., X.L. Wu, and K. Schaich. 2005. Standardized methods for the determination of antioxidant capacity and phenolics in foods and dietary supplements. J. Agr. Food Chem. 53:4290-4302.

Pulido, R., L. Bravo, and F. Saura-Calixto. 2000. Antioxidant activity of dietary polyphenols as determined by a modified ferric reducing/ antioxidant power assay. J. Agr. Food Chem. 48:3396-3402.

Reay, P.F., R.H. Fletcher, and V.J. Thomas. 1998. Chlorophylls, carotenoids and anthocyanin concentrations in the skin of 'Gala' apples during maturation and the influence of foliar applications of nitrogen and magnesium. J. Sci. Food Agr. 76:63-71.

Reay, R.F. and J.E. Lancaster. 2001. Accumulation of anthocyanins and quercetin glycosides in 'Gala' and 'Royal Gala' apple fruit skin with UV-B visible irradiation: Modifying effects of fruit maturity, fruit side, and temperature. Sci. Hort. 90:57-68.

Reig, G., S. Alegre, F. Gatius, and I. Iglesias. 2013. Agronomical performance under Mediterranean climatic conditions among peach (Prunus persica (L.) Batsch) cultivars originated from different breeding programmes. Sci. Hort. 150:267-277.

Rice-Evans, C., N. Miller, and G. Paganga. 1996. Structure-antioxidant activity relationships of flavonoids and phenolic acids. Free Radic. Biol. Med. 20:933-956. 
Ryan, K.G., E.E. Swinny, K.R. Markham, and C. Winefield. 2002. Flavonoid gene expression and UV photoprotection in transgenic and mutant petunia leaves. Phytochemistry 59:23-32.

Scalzo, J., A. Politi, N. Pellegrini, B. Mezzetti, and M. Battino. 2005. Plant genotypes affect total antioxidant capacity and phenolic contents in fruit. Nutrition 21:207-213.

Schreiner, R.P., C.F. Scagel, and J. Lee. 2013. N, P, and K supply to pinot noir grapevines: Impact on berry phenolics and free amino acids. Amer. J. Enol. Viticult. 64:26-38.

Serrano, M., F. Guillén, D. Martínez-Romero, S. Castillo, and D. Valero. 2005. Chemical constituents and antioxidant activity of sweet cherry at different ripening stages. J. Agr. Food Chem. 53:2741-2745.

Sherman, W.B. and P.M. Lyrene. 1985. Progress in low-chill plum breeding. Proc. Florida State Hort. Soc. 98:164-165.

Simonne, A.H., J.M. Fuzere, E. Simonne, R.C. Hochmuth, and M.R. Marshall. 2007. Effects of nitrogen rates on chemical composition of yellow grape tomato grown in a subtropical climate. J. Plant Nutr. 30:927-935.

Sogawa, S., Y. Nihro, H. Ueda, A. Izumi, T. Miki, H. Matsumoto, and T. Satoh. 1993. 3, 4-Dihydroxy chalcones as potent 5-1ipoxygenase and cyclooxygenase inhibitors. J. Med. Chem. 36:3904-3909.

Spanos, G.A. and R.E. Wrolstad. 1990. Influence of processing and storage on the phenolic composition of Thompson Seedless grape juice. J. Agr. Food Chem. 38:1565-1571.

Srivastava, A., P. Greenspan, D.K. Hartle, J.L. Hargrove, R. Amarowicz, and R. Pegg. 2010. Antioxidant and anti-inflammatory activities of polyphenolics from southeastern U.S. range blackberry cultivars. J. Agr. Food Chem. 58:6102-6109.

Stefanelli, D., I. Goodwin, and R. Jones. 2010. Minimal nitrogen and water use in horticulture: Effects of quality and content of selected nutrients. Food Res. Intl. 43:1833-1843.

Stewart, A.J., S. Bozonnet, W. Mullen, G.I. Jenkins, M.E.J. Lean, and A. Crozier. 2000. Occurrence of flavonols in tomatoes and tomatobased products. J. Agr. Food Chem. 48:2663-2669.

Stewart, A.J., W. Chapman, G.I. Jenkins, I. Graham, T. Martin, and A. Crozier. 2001. The effect of nitrogen and phosphorous deficiency on flavonol accumulation in plant tissues. Plant Cell Environ. 24:11891197.
Strissel, T., H. Halbwirth, U. Hoyer, C. Zistler, K. Stich, and D. Treutter. 2005. Growth-promoting nitrogen nutrition affects flavonoid biosynthesis in young apple (Malus domestica Borkh.) leaves. Plant Biol. 7:677-685.

Sun, J., Y.F. Chu, X.Z. Wu, and R.H. Liu. 2002. Antioxidant and antiproliferative activities of common fruits. J. Agr. Food Chem. 50:7449-7454.

Tomas-Barberan, F.A., M.I. Gil, P. Cremin, A.L. Waterhous, B. Hess-Pierce, and A.A. Kader. 2001. HPLC-DAD-ESIMS analysis of phenolic compounds in nectarines, peaches and plums. J. Agr. Food Chem. 49:4748-4760.

Tomas-Barberan, F.A. and R.J. Robins. 1997. Phytochemistry of fruit and vegetables. Oxford Univ. Press, New York, NY.

Tulipani, S., B. Mezzetti, F. Capocasa, S. Bompadre, J. Beekwilder, C. H.R. De Vos, E. Capanoglu, A. Bovy, and M. Battino. 2008. Antioxidants, phenolic compounds, and nutritional quality of different strawberry genotypes. J. Agr. Food Chem. 56:696-704.

Urbanczyk-Wochniak, E. and A.R. Fernie. 2005. Metabolic profiling reveals altered nitrogen nutrient regimes have diverse effects on the metabolism of hydroponically-grown tomato (Solanum lycopersicum) plants. J. Expt. Bot. 56:309-321.

Vashisth, T., R. Singh, and R. Pegg. 2011. Effects of drying on the phenolics content and antioxidant activity of muscadine pomace. Lebensm. Wiss. Technol. 44:1649-1657.

Wade, J., B. Holzapfel, K. Degaris, D. Williams, and M. Keller. 2004. Nitrogen and water management strategies for wine-grape quality. Acta Hort. 640:61-67.

Winkel-Shirley, B. 2002. Biosynthesis of flavonoids and effects of stress. Curr. Opin. Plant Biol. 5:218-223.

Yoshida, Y., T. Goto, M. Hirai, and M. Masuda. 2003. Anthocyanin accumulation in strawberry fruits as affected by nitrogen nutrition. Acta Hort. 567:357-360.

Zhishen, J., T. Mengcheng, and W. Jianming. 1999. The determination of flavonoid contents in mulberry and their scavenging effect on superoxide radicals. Food Chem. 64:555-559.

Zhu, W., X. Lin, C. Jin, Y. Zhang, and P. Fang. 2009. Effects of nitrogen application rates on antioxidant contents and antioxidative activities in chinese cabbage (Brassica chinensis L.). J. Zhejiang Univ. Agr. Life Sci. 35:299-306. 